\title{
The Impact of Audit Committee Characteristics on Audit Report Time Lag: Evidence From Ghana
}

\author{
Millicent Selase Afenya ${ }^{1}$, Benedict Arthur ${ }^{2}$, Williams Kwarteng ${ }^{3}$, Gabriel Kyeremeh ${ }^{1}$ \\ 1.Accounting School; Zhongnan University of Economics and Law, Wuhan, China \\ 2.School of Finance; Zhongnan University of Economics and Law, Wuhan, China \\ 3.Accounting Department; Multisoft solutions, Ghana \\ Corresponding author: millicentafenya@gmail.com
}

\begin{abstract}
The study examines the impact of audit committee characteristics on audit reporting time lag of Ghanaian publicly traded companies. We used the size of the audit committee, gender diversity, and financial expertise to measure the characteristics of the audit committee as against the number of days between financial year-end date and audit report completion. The study predicted and found a negative relationship between audit committee gender diversity and audit report time lag. Also, a negative association between the audit committee financial expertise and audit report time lag was established. Furthermore, a negative association was affirmed between audit report time lag and gender diversity of the committee. The study therefore concluded that the audit committee characteristics leads to audit efficiency indicating that audit committee promotes the prompt delivery of the audit report. As a result, the study suggests that companies consider variegating their audit committee board on these characteristics. Keywords: Audit Committee, Audit report time lag, Board size, financial expertise, Gender diversity.
\end{abstract}

DOI: $10.7176 /$ RJFA/13-4-01

Publication date: February $28^{\text {th }} 2022$

\section{Introduction}

The timeliness of financial report is equally of great importance to stakeholders just as the quality of the financial report. As such, one of the most significant characteristics of audit quality, according to regulators, professional accountants, and auditors, is timeliness of the audit report (McGee and Tarangelo, 2008; Soltani 2002; Hendriksen and Breda, 1992). A well-written audit report is of little use to management if it is received too late to be fully considered and acted upon. Timely audit reports can assist a company in planning for the coming year. Organizations will also be able to make better budget and financial decisions if financial statements are provided on time. Therefore, enhancing financial reporting timeliness boosts value to users (Behn et al., 2006) but when delayed leads to adverse consequences (Carmichael et al., 2011; Mande \& Son 2011).

In recent years, audit committees have attracted massive attention as an important corporate governance mechanism. The Audit Committee is in charge of overseeing the audit engagement (Sarbanes-Oxley Act of 2002, 2002), which is a critical component of financial reporting timeliness (Afify 2009). Corporate governance committees and regulators globally have addressed the need for an operative audit committee, with many making audit committees mandatory for listed companies. However, the mere existence of the audit committee does not necessarily guarantee translation into competent committee (Carcello and Neal 2003; Abbott and Parker 2000, 2001; Raghunandan et al. 2001; Beasley et al. 2000). Therefore, attention has shifted to the composition and duties carried out by these audit committees. Recommendations have been stressed on the independence and competence of committee members and the frequency of committee meetings (Smith Report, 2003; Australian Stock Exchange Corporate Governance Council (ASX), 2003; National Association of Corporate Directors (NACD), 1999). Nevertheless, research indicates a considerable disparity in the recommended structure and functions of audit committees across different jurisdictions (Collier \& Zaman, 2005).

Theoretically, the knowledge about the determinants of audit report lag suggests that the efficiency of the audit committee can partly drive the timeliness of the audit. Audit committees simplify the role of internal auditors and, in general, strengthen internal controls. If the audit committee acts as an alternative to the external auditor in overseeing management, a more effective audit committee reduces the need for external audits and thus reduces audit delays. On the other hand, if the audit committee complements the work of the external auditor, the audit committee will require more external audit work, which can increase audit delays. This reasoning implies that well-managed companies have a low external audit workload, and poorly managed companies have a high external audit workload. However, the impulse of the subject matter remains an empirical issue. Therefore, this paper seeks to empirically examine the relationship between audit committee characteristics (Audit committee financial expertise, Size and Diversity) and audit report lag.

We hypothesize that the following audit committee characteristics (financial expertise, size, and diversity) will result in timely audit reports. Our hypotheses are supported by two assumptions. First, previous research suggests that the Audit Committee may take actions under its control with results related to improving the quality of audits, such as increased going-concern alterations for distressed firms (Carcello and Neal 2000). Consequently, 
this will decrease the workload of external auditors and their audit report lag. The reason being that audit committees influence the scope or coverage of audit in a firm (DeZoort 1997; BRC,1999). Thus, given the investor maximizing wealth interest, audit committees seeking a higher level of oversight ensure a necessary robust internal control mechanism. Second, preceding research has shown that certain characteristics of the audit committee, such as the diversity and level of financial expertise, have a substantial impact on how the committee performs its duties. (Beasley et al. 2009; Carcello and Neal 2000; Raghunandan et al. 2001). Therefore, the increased in technical competency or the efficiency of the audit committee will reduce the amount of time needed for the committee to sufficiently discuss pertinent accounting issues with the auditor and management, and hence, reduction in audit report lag.

This research contributes to the audit and corporate governance literature by throwing light on the equivocal relationship between audit committee and audit report lag. On the one hand, studies (Farooq et al., 2018; Abernathy et al., 2014; Hashim \& Rahman 2012; Vafeas et al. 2007, Felix et al. 2001; DeZoort 1997) show that audit committees may take over the task that external auditors conduct. Accordingly, the existence of more effective audit committees may lead to timely audit report or decrease in audit report lag. Conversely, other research suggests that an audit committee could supplement the work of external auditors (Bhuiyan and D'Costa 2020; Lee and Mande 2005; Vafeas and Waegelein 2007; Carcello et al. 2002). As a result, the audit committee will require a higher degree of audit assurance, which may necessitate a larger audit scope and hence longer audit repot lag. Moreover, there are other studies (Ahmed and Che-ahmad 2016; Salleh 2015; Afify 2009) also in the middle of this continuum which posit no significant impact of these audit committee characteristics on external audit report lag. The discrepancy in results as to whether audit committees and external auditors are substitutes or complements allows for more investigation of the relationship.

Therefore, employing data from a Sub-Saharan country like Ghana, which has received little to no attention on this vital nexus, this study provides new insight into the subject. In addition, by examining gender diversity as a variable of measurement for audit committee features, this study contributes to the burgeoning literature on gender diversity. Finally, the study's findings will provide useful information to managers, policymakers, and regulatory agencies in Ghana and other Sub-Saharan African countries about the critical significance of audit committee features in improving financial report timeliness.

The remaining sections of the paper are organized as follows: Section two contains a literature review and the formulation of hypotheses; Section three has an explanation of the research data and methods; Section four contains empirical results and interpretations; and Section five contains research conclusions and recommendations.

\section{Literature Review and Hypotheses Development \\ 2.1 Theoretical framework}

Audit is viewed as an important part of corporate governance since it provides an impartial examination of the organization's financial status. Managerial and shareholder disputes arise as a result of the distinction between ownership and control in nascent businesses. Companies are obligated to utilize control mechanisms such as audit committees to reduce agency costs and information asymmetry as a result of the conflict between the principal and the agent (Kalbers \& al 1998). According to Pincus and Rusbarsky (1989), audit committees are typically employed to improve the quality of information flows from the agent to the principal in instances where agency costs are significant. In view of that, managers are encouraged to provide acceptable financial statements to specify the return generated by the companies, according to the agency theory, to ensure the success of an audit committee. Therefore, the agency theory asserts that the existence of an audit committee inside the board of directors is sufficient to ensure financial statement credibility. However, existing research (Carcello and Neal 2003; Abbott and Parker 2000, 2001; Raghunandan et al. 2001; Beasley et al. 2000) has concluded that the mere existence of an audit committee does not necessarily imply that it is effective in performing its oversight, but rather that it possesses certain key characteristics. In line with this assertion, this study explores the following audit committee features: size, expertise, and gender diversity.

\section{Audit Committee}

An audit committee is a section of an organization's board of directors that is in charge of monitoring the organization's financial reports, disclosure, and authenticating its accuracy. They are usually independent outside directors; whose primary responsibility is to provide an objective and an unbiased view of the company's accounting practices and principles. They are outside directors because this is to ensure the neutrality of the audit process and remove all ideas and perceptions of conflict of interest during the audit procedure. An effective audit committee reflect characteristics which are impartial, timely, focused and proactive to responsibilities rather than reactive.

\section{Audit Committee Financial Expertise}

Audit committee financial expertise describes the expert skill or knowledge in accounting and finance possess by the members of the audit committee. A corporation must report whether any member of its audit committee is 
eligible for "audit committee financial expert" status under SEC requirements (ACFE). As a result, audit committees with a strong understanding of auditing can decipher auditor judgements and the content of management-external auditor disagreements. According to Yang et al. (2005) and Carcello et al. (2005), the audit committee must have the requisite expertise primarily in accounting and financial reporting to fulfil its supervision, internal control, and financial reporting responsibilities (2006). Audit committee members' experience, according to Choi et al. (2004), can be categorized into five categories: financial expertise, accountancy, university professors or former academics, employee expertise, and legal expertise.

\section{Audit Committee Gender Diversity}

Gender diversity on the audit committee entails an equal number of men and women. In other words, audit committee gender diversity refers to the committee's inclusive or fair representation of men and women of various genders. Extant literature (Bernardi et al. 2002, 2005; Bear et al., 2010) have shown that committees with multiple female directors are likely to operate differently than committees with all male directors. However, only few research has investigated the effects of gender inequalities on audit committee composition. Female audit committee members, according to Dennis and Kunkel (2004), are better equipped, energetic, potent, emotionally stable, cautious, independent, and less vindictive than male managers. As a result, a female member of the audit committee may be more sensitive to the firm's potentially deceptive financial reporting. Nevertheless, according to $\mathrm{Li}$ and Wearing (2004), female independent directors have a lower chance of being promoted to positions like head of the audit committee.

\section{Audit Committee Size}

The size of the audit committee refers to the total number of people that constitute the audit committee. According to Abu et al (2018) the group of persons that form the committee are usually chosen from outside the firm to provide an impartial and fair appraisal of the company's practices. Literature suggest that an audit committee should be diverse and diverse enough to portray a balance of views and experience, yet small enough to function efficiently (Xie et al 2003; Anderson et al 2004). According to Xie et al 2003, an audit committee should have a minimum of 3 members, excluding invitees and co-opted persons. The quorum for each meeting should be stated and defined in the audit committee's byelaws or guidelines.

\section{Audit Report Time Lag}

Audit report time lag refers to the number of days between the financial year-end date and audit report completion. Firms' timely publication of financial data is an important part of financial reporting since it plays a critical role in the information economy and in stakeholders' investment decisions. By failing to provide timely information to key stakeholders, audit report lag jeopardizes the validity of financial data. In theory, it is argued that the value of information is inversely proportional to the time it takes to prepare financial statements; specifically, the longer the auditor takes to complete the audit, as mirrored in the audit report lag, the stronger the signal to the market that there may be negative issues arising from the audit.

\subsection{Hypothesis Development}

\section{Audit committee size and audit report time lag}

Securities exchange commission specifies the audit committee size should be minimum of three members. It is argued that a higher number of audit committee size can handle companies' issues

efficiently and effectively (Sultana et al., 2015). Hillman and Dalziel (2003) asserted that an increase in audit committee number leads to low participation by some directors that undermine the control, oversight and monitoring functions. Bédard and Gendron (2010) established the fact that an audit committee with fewer members has diversified expertise and can ensure the appropriate monitoring. Larger audit committee size can detect potential problems in the financial reporting process. This is only possible if a higher number of committee size adds up to the resources allocated to improve the quality of oversight. Li, Pike and Haniffa (2008) and Persons (2009) show that the audit committee size enhances corporate disclosures. The study evidence of Mohamad-Nor, Shafie and Wan-Hussin (2010) indicated that firms with more members in the audit committee are more likely to produce audit reports quickly. Zaitul (2010) argued that several board characteristics affect the timeliness of financial reporting, especially board sizes, board shareholding, board multiple directorship and length of service are significantly related to management report lag. Akle (2011) asserted that listed companies in Egypt could produce an annual financial report in a short time frame since the application of corporate governance principles. Based on the above arguments, the study hypothesized that H1: There is a negative relationship between audit committee size and audit report time lag.

\section{Audit committee financial expertise and audit report time lag}

Financial reporting process and oversight is the crucial responsibility of audit committee, and the responsibility can only be highly achieved with members of the board with understanding and experience in finance (Bédard, Chtourou and Courteau 2004). Salleh, Baatwah, and Ahmad (2017) argued that companies without a member with financial expertise on their audit committee would suffer from financial problems. Yatim, Kent, \& Clarkson (2006) established that an audit committee that has members with financial expertise significantly increases the demand 
for higher audit quality. The agency theory argues that the presence of financial experts improves the monitoring duty of audit committee over the internal controls and facilitates the efficiency of external auditor (Sultana et al., 2015). Resource dependency advocates believe that having financial professionals on the audit committee gives the subcommittee more control over financial accounting information and audit judgments. The position of this study is that an audit committee with financial expertise tends to decrease the time taken to audit the financial reports. In line with the literature, we hypothesized that $\boldsymbol{H}$ : There is a negative relationship between audit committee, financial expertise and audit report time lag.

\section{Audit committee Gender diversity and audit report time lag}

Gender is another type of power relationship affected by the corporate environment in which it exists. Many authors using data from developed economies have also addressed research questions relevant to the efficacy of the board (Fondas \& Sassalos, 2000; Huse \& Grethe-Solberg, 2006; Miller \& Del Carmen Triana, 2009; Nielson \&Huse, 2010) and audit committee when women are members. Dennis and Kunkel (2004) argued that audit committee members with women are more equipped, active, potent, emotionally stable, circumspect, independent, and more welcoming than are male managers. A female audit committee may be more sensitive for a firm's potential fraudulent financial reporting. Bernardi and Threadgill (2010), found out that companies with a higher percentage of females on the board as compared to members with only men engage in activities demonstrating corporate social responsibility hence enormous firm performance. Li and Wearing (2004) asserted that audit committees with one or more female directors would function differently than audit committees with all-male directors. Kuang and Chen (2011) suggested that female representatives on the Chinese corporate board are related to increasing request for higher audit quality. This study argues that the diligence of the female members on the committee aid the work on internal audit function; therefore, this reduces the scope of external audit. Consequently, the study hypothesized that $\boldsymbol{H} 3$ : There is a negative relationship between audit committee gender diversity and audit report time lag.

\section{Research methodology}

The key methodological strategy adopted in this study are discussed in this part. The variables utilized in the study, how they were measured, and where they were sourced from are all covered in this section.

\subsection{Data sources and Measurement of study variables}

Secondary data was acquired from financial statements of companies registered on the Ghana stock exchange from 2008 to 2019. Due to the lack of data on the essential study variables, the study sample was limited to 25 companies out of the 38 companies registered on the Ghana stock exchange. The dependent or explained variable for the study is audit report time lag. This variable is measured by the natural log of the number of days between financial yearend date and audit report completion, which is consistent with previous studies, like Sultana et al. (2015). The audit committee characteristics, which include audit committee size, expertise, and gender diversity, are used as independent or explanatory variables in the study. The size of the audit committee was calculated using the total number of members who make up the committee. The number of audit committee members with a financial background was also used to gauge financial expertise. In addition, the ratio of the total number of females on the audit committee was used to calculate gender diversity.

Furthermore, in line with previous literature, we control the likelihood of other variables influencing the relationships between the independent variable and dependent variables, (Sultana et al. 2015; Salleh 2015; Beasley et al. 2000; Miglani and Ahmed 2019; Benedict et al., 2021). To account for the variability across the firms, we included audit committee meetings, board independence, board size, leverage, firm age, and firm size as covariates in the regression analysis. Audit committee meetings is estimated with the number of meetings of the audit committee members per year. The value of the big 4 audit firm is calculated as 1 if the company is audited by any of the big four, and 0 otherwise. The percentage of non-executive board members to total corporate board members is used to calculate non-executive directorships. Total debts were divided by total assets to determine the company's leverage. The value of the big 4 audit firm is calculated as 1 if the company is audited by any of the big four, and 0 otherwise. The total number of individuals on the governing board is used to determine board size. The number of years a company has been in business is referred to as its age. Lastly, the natural log of total assets is used to calculate business size.

\subsection{The Empirical Strategy and Model}

The study used a multivariate ordinary least square regression with fixed effect purposely to control for various firm level heterogeneity features that could possibly affect the empirical relationship between the main variables of interest, audit report time lag and audit committee characteristics (size, expertise, and gender diversity). In addition, robust standard errors were included in the regression to account for any potential serial correlation or hetreoscedacity concerns. The empirical model that was used in the study is shown below. 


$$
\begin{gathered}
A T L_{i t}=\beta_{0}+\beta_{1} A C S_{i t}+\beta_{2} A C E_{i t}+\beta_{3} A C G_{i t}+\beta_{4} B S_{i t}+\beta_{5} \text { FirmSize }_{i t}+\beta_{6} A C M_{i t}+\beta_{7} B I_{i t}+\beta_{8} B I G 4_{i t} \\
+\beta_{9} \text { Firm }_{\text {irm }} \text { Age } \\
\text { it }
\end{gathered}
$$

Where ATL is Audit report time lag, ACG is the audit committee gender diversity, ACS is audit committee size, ACE is the audit committee financial expertise, BS is the board size, ACM is audit committee meetings, BI is the board independence (non-executive director), Big4 is audit by the big four audit firm, Firm.Age is firm age, FirmSize is firm size, Lev is firm leverage, year dummy is year fixed effect and firm dummy is firm fixed effect.

\section{Empirical Results and Discussion \\ 4.1 Descriptive Statistics}

Table 1 shows the summary statistics of the study. The results shows that audit report time lag has a minimum of 42 days and a maximum of 234 days. The average days between the financial year-end and submission of the signed audited report was 92 days. By implication, in Ghana most audited annual reports for companies listed on the Stock Exchange are ready by the third month (March) each year. Most of the company's financial year starts from January to December in the calendar year. Table 1 also reveals that the average size of an audit committee in Ghana is 4.62 members, with an average of two (2) members having financial knowledge (at least a bachelor's degree in finance and accounting). The findings revealed that businesses listed on the stock exchange follow Securities Exchange Commission standards, which stipulate that the audit committee board must have at least three (3) members. In several publicly traded companies, it was also discovered that the audit committee has at least one (1) financial expert member. Meanwhile, every employee at a number of other businesses has had that experience. Table 1 shows that the average gender diversity of audit committee members is $21 \%$. Some firms reported a gender diversity of 0.00 percent, implying that no females served on their audit committee. For this study, the minimal value of non-executive directors (board independence) was 29 percent, and the audit committee met only five (5) times each year on average. The average value of board independence for companies in the sample was 0.731 , with a standard deviation of 14.547 . The minimum value of board independence for companies in the sample was 29 percent, with a maximum of 91 percent. Table 1 further shows that the smallest board size is four and the highest board size is twelve, with an average board size of eight and a standard deviation of 1.813. With a standard deviation of 24.539, the average company age was 46.54 (ranging from 3 to 124). The average business size was 8.522 , with a standard deviation of 0.902 (from 6.648 to 10.12), while the average number of big4 firms was 0.859 , with a standard deviation of 0.349 . (minimum of 0 and maximum of 1 ). Furthermore, the firms 'leverage ranges from 0.022 to 0.958 , with a mean of 0.602 and a standard deviation of 0.245 .

Table 1. Summary Statistics

\begin{tabular}{llllll}
\hline Variable & Obs & Mean & Std.Dev. & Min & Max \\
\hline $\begin{array}{l}\text { Dependent variables } \\
\text { ATL }\end{array}$ & 308 & 92.00 & 63.12 & 42.00 & 234.00 \\
$\begin{array}{l}\text { Independent variables } \\
\text { ACS }\end{array}$ & 308 & 4.6209 & 1.142 & 3.00 & 10.00 \\
ACE & 308 & 2.0141 & 1.196 & 1.00 & 4.00 \\
ACG & 308 & 0.178 & 0.231 & 0.00 & 0.60 \\
Control variables & & & & & 14.00 \\
ACM & 308 & 4.8072 & 6.132 & 4.00 & 12 \\
BS & 308 & 8.03 & 1.813 & 4 & 0.91 \\
BI & 308 & 0.731 & 0.145 & 0.29 & 124 \\
Firm.Age & 308 & 46.54 & 24.539 & 3 & 1 \\
BIG4 & 308 & 0.859 & 0.349 & 0 & 10.12 \\
FirmSize & 308 & 8.522 & 0.902 & 6.648 & 0.958 \\
Lev & 308 & 0.602 & 0.245 & 0.022 & \\
\hline
\end{tabular}

ATL is audit report time lag, ACS is audit committee size, ACE is the audit committee financial expertise, ACG is the audit committee gender diversity, BS is the board size, ACM is audit committee meetings, BI is the board independence (non-executive director), Big4 is audit by the big four audit firm, Firm.Age is firm age, FirmSize is firm size, Lev is firm leverage.

\subsection{Correlation Matrix}

To assess for probable multicollinearity issues among the variables, correlation analysis was used. The Pearson pair-wise correlations between our primary variables are shown in Table 2. Except for firm age, all of the independent factors are highly connected with audit report time lag. Most crucially, the explanatory factors have some meaningful but weak association. In other words, except for the connection between the dependent variables and the independent factors, there was little correlation among the independent variables. To be more specific, no other explanatory variable has a correlation greater than 0.27 , with the exception of audit committee and board size, which have the greatest correlation of 0.36 . Serious multicollinearity, according to Hair et al. (2009), exists 
when the correlation between two or more explanatory variables is greater than 0.8 . As a result, it is inferred that the data or variables do not have a multicollinearity problem, in accordance with this assumption.

\begin{tabular}{|c|c|c|c|c|c|c|c|c|c|c|c|}
\hline Variables & (1) & (2) & (3) & (4) & (5) & (6) & (7) & (8) & (9) & (10) & (11) \\
\hline (1) ATL & 1.000 & & & & & & & & & & \\
\hline (2) ACS & $\begin{array}{r}-0.052 * * \\
(0.032)\end{array}$ & 1.000 & & & & & & & & & \\
\hline (3) $\mathrm{ACE}$ & $\begin{array}{r}-0.416^{* * * *} \\
(0.001)\end{array}$ & $\begin{array}{l}-0.007 \\
(0.810)\end{array}$ & 1.000 & & & & & & & & \\
\hline (4) ACG & $\begin{array}{r}-0.030 * * * \\
(0.013)\end{array}$ & $\begin{array}{r}-0.023 \\
(0.467)\end{array}$ & $\begin{array}{l}0.135^{*} \\
(0.059)\end{array}$ & 1.000 & & & & & & & \\
\hline (5) $\mathrm{ACM}$ & $\begin{array}{c}-0.002^{*} \\
(0.041)\end{array}$ & $\begin{array}{l}-0.020 \\
(0.515)\end{array}$ & $\begin{array}{c}-0.036 \\
(0.246)\end{array}$ & $\begin{array}{l}-0.022 \\
(0.475)\end{array}$ & 1.000 & & & & & & \\
\hline (6) $\mathrm{BS}$ & $\begin{array}{l}0.023^{*} \\
(0.049)\end{array}$ & $\begin{array}{l}-0.010^{*} \\
(0.004)\end{array}$ & $\begin{array}{c}-0.075^{*} \\
(0.051)\end{array}$ & $\begin{array}{l}-0.025 \\
(0.425)\end{array}$ & $\begin{array}{r}-0.040 \\
(0.200)\end{array}$ & 1.000 & & & & & \\
\hline (7) BI & $\begin{array}{r}0.036^{* * *} \\
(0.023)\end{array}$ & $\begin{array}{r}0.008 \\
(0.795)\end{array}$ & $\begin{array}{r}0.044 \\
(0.152)\end{array}$ & $\begin{array}{r}-0.006 \\
(0.841)\end{array}$ & $\begin{array}{r}-0.028 \\
(0.368)\end{array}$ & $\begin{array}{r}0.069 \\
(0.025)\end{array}$ & 1.000 & & & & \\
\hline (8) Firm.Age & $\begin{array}{l}-0.019 \\
(0.105)\end{array}$ & $\begin{array}{r}0.034 \\
(0.269)\end{array}$ & $\begin{array}{l}-0.047 \\
(0.127)\end{array}$ & $\begin{array}{r}0.024 \\
(0.446)\end{array}$ & $\begin{array}{r}-0.012 \\
(0.693)\end{array}$ & $\begin{array}{l}-0.046 \\
(0.138)\end{array}$ & $\begin{array}{r}-0.004 \\
(0.895)\end{array}$ & 1.000 & & & \\
\hline (9) BIG4 & $\begin{array}{r}0.003 * * * \\
(0.002)\end{array}$ & $\begin{array}{r}0.036 \\
(0.250)\end{array}$ & $\begin{array}{r}-0.025 \\
(0.418)\end{array}$ & $\begin{array}{r}0.019 \\
(0.540)\end{array}$ & $\begin{array}{r}-0.011 \\
(0.725)\end{array}$ & $\begin{array}{c}-0.104^{*} \\
(0.081)\end{array}$ & $\begin{array}{r}-0.043 \\
(0.164)\end{array}$ & $\begin{array}{r}-0.016 \\
(0.615)\end{array}$ & 1.000 & & \\
\hline (10) FirmSize & $\begin{array}{l}0.139^{*} \\
(0.049)\end{array}$ & $\begin{array}{l}0.077^{*} \\
(0.013)\end{array}$ & $\begin{array}{l}0.138^{*} \\
(0.061)\end{array}$ & $\begin{array}{r}0.053 \\
(0.085)\end{array}$ & $\begin{array}{r}-0.014 \\
(0.642)\end{array}$ & $\begin{array}{l}-0.272^{*} \\
(0.060)\end{array}$ & $\begin{array}{r}0.028 \\
(0.371)\end{array}$ & $\begin{array}{r}0.024 \\
(0.435)\end{array}$ & $\begin{array}{r}0.033 \\
(0.291)\end{array}$ & 1.000 & \\
\hline (11) Lev & $\begin{array}{l}0.028^{*} \\
(0.052)\end{array}$ & $\begin{array}{c}-0.122^{*} \\
(0.000)\end{array}$ & $\begin{array}{c}-0.132^{*} \\
(0.071)\end{array}$ & $\begin{array}{l}0.092^{*} \\
(0.063)\end{array}$ & $\begin{array}{l}-0.031 \\
(0.312)\end{array}$ & $\begin{array}{l}0.649^{*} \\
(0.070)\end{array}$ & $\begin{array}{l}0.108^{*} \\
(0.060)\end{array}$ & $\begin{array}{c}-0.070^{*} \\
(0.024)\end{array}$ & $\begin{array}{r}-0.234 * * \\
(0.000)\end{array}$ & $\begin{array}{c}-0.349^{*} \\
(0.073)\end{array}$ & 1.000 \\
\hline
\end{tabular}

Table 2. Correlation analysis

Note: $* * * \mathrm{p}<0.01, * * \mathrm{p}<0.05, * \mathrm{p}<0.1$. ATL is audit report time lag, ACS is audit committee size, ACE is the audit committee financial expertise, ACG is the audit committee gender diversity, BS is the board size, ACM is audit committee meetings, BI is the board independence (non-executive director), Big4 is audit by the big four audit firm, Firm.Age is firm age, FirmSize is firm size, Lev is firm leverage.

\subsection{Regression Analysis}

The regression results for the impact of audit committee features on audit report time lag are presented in Table 3 .

Table 3. Regression Results

\begin{tabular}{|c|c|c|}
\hline ATL (Audit Report Time Lag) & $\begin{array}{c}\text { Model } \\
\text { (1) }\end{array}$ & $\begin{array}{l}\text { Model } \\
\text { (2) }\end{array}$ \\
\hline \multirow[t]{2}{*}{$\mathrm{ACS}$} & $-0.440 * * *$ & $-0.232 * * *$ \\
\hline & $(0.112)$ & $(0.025)$ \\
\hline \multirow[t]{2}{*}{$\mathrm{ACE}$} & $-0.613^{* * *}$ & $-0.421 * * *$ \\
\hline & $(0.033)$ & $(0.102)$ \\
\hline \multirow[t]{2}{*}{ ACG } & $-0.365 * * *$ & $-0.224 * * *$ \\
\hline & $(0.100)$ & $(0.040)$ \\
\hline \multirow[t]{2}{*}{$\mathrm{ACM}$} & & $-0.028 *$ \\
\hline & & $(0.015)$ \\
\hline \multirow[t]{2}{*}{$\mathrm{BS}$} & & $0.037 * * *$ \\
\hline & & $(0.010)$ \\
\hline \multirow[t]{2}{*}{$\mathrm{BI}$} & & $-0.019 * *$ \\
\hline & & $(0.009)$ \\
\hline \multirow[t]{2}{*}{ Firm.Age } & & 0.032 \\
\hline & & $(0.046)$ \\
\hline \multirow[t]{2}{*}{ BIG4 } & & $-0.512 * * *$ \\
\hline & & $(0.046)$ \\
\hline \multirow[t]{2}{*}{ FirmSize } & & $-0.027 * *$ \\
\hline & & $(0.011)$ \\
\hline \multirow[t]{2}{*}{ Lev } & & $0.063 * * *$ \\
\hline & & $(0.013)$ \\
\hline \multirow[t]{2}{*}{ Constant } & $0.522 * * *$ & $0.512 * * *$ \\
\hline & $(0.015)$ & $(0.046)$ \\
\hline Obs. & 308 & 308 \\
\hline $\mathrm{R}$-squared & 0.433 & 0.621 \\
\hline Year FE & NO & YES \\
\hline Firm FE & $\mathrm{NO}$ & YES \\
\hline \multicolumn{3}{|c|}{$\begin{array}{l}\text { Note: } * * * \mathrm{p}<0.01, * * \mathrm{p}<0.05,{ }^{*} \mathrm{p}<0.1 \text {. ATL is audit report time lag, ACS is audit committee size, ACE is the audit } \\
\text { committee financial expertise, ACG is the audit committee gender diversity, BS is the board size, ACM is audit } \\
\text { committee meetings, BI is the board independence (non-executive director), Big4 is audit by the big four audit } \\
\text { firm, Firm. Age is firm age, FirmSize is firm size, Lev is firm leverage. }\end{array}$} \\
\hline
\end{tabular}


Model one of the regression results in table 3 shows a regression with no control factors and fixed effects, whereas model two shows a regression with both control variables and fixed effects. The R-squared improves dramatically in model 2 when fixed effects and control variables are incorporated, as evidenced by the regression results. This finding suggests that some observable and unobserved firm-level time-invariant factors have significant explanatory power on the relationship, and hence must be controlled for. Robust error was also used to account for any worries about heteroskedasticity and autocorrelation. The impact of audit committee features on audit report time lag is strongly negative in both models, as evidenced by the results in table 3 . Despite a decrease in the value of the audit committee characteristics coefficients in model 2 (regression with controlled variables and fixed effects), the audit report time lag impact remains consistently negative and substantial. As a result, if all other factors remain constant, a unit rise in the related audit committee characteristics will result in a corresponding unit drop-in audit report time lag.

According to model 2, an increase in audit committee size of one unit will result in a 0.232 unit drop-in audit report time lag. As a result, audit fees appear to be lower in companies with a larger audit committee. The findings corroborate hypothesis 1 , which suggests that audit committee size and audit fee have a negative relationship. The findings are in line with previous research, such as Mohamad-Nor et al (2010), Akle (2011), Sultana et al. (2015) and Farooq et al. (2018) who stated that a larger audit committee has the ability to deal with a company's difficulties in a cost-effective and efficient manner. However, this finding contrasts the finding of other studies such as Afify (2009); and Ahmed and Che-ahmad (2016) who documented no significant relationship between audit committee size and audit report time lag.

In terms of financial expertise on the audit committee, an increase in the number of financial specialists on the committee will result in a 0.421 unit reduction in audit report time lag. Audit reports are apparently timely in organizations where at least one member of the audit committee has accounting or financial experience. The findings also support hypothesis 2 , which states that audit committee financial expertise and audit report time lag have a negative relationship. The findings of the study are consistent with those of Sultana et al (2015), Salleh et al (2017), Abernathy (2014), who found that audit committees with more financial expertise have timely audit reports. This finding, on the other hand, contradicts the findings of prior studies, which found no link, and other studies which found positive connection between audit committee expertise and audit report time lag (Raweh et al., 2019; Habib and Bhuiyan, 2011).

Concerning audit committee gender diversity, the results in model two show that a percentage increase in audit committee diversity leads to a 0.224 unit reduction in audit report time lag. This finding suggests that companies with more female members on audit committees tend to have timely audit report. Similarly, this evidence supports hypothesis 3, which indicates that audit report time lag is inversely associated to gender diversity on audit committees. The findings of the study are likewise in line with those of Ahmed and Che-Ahmad (2016), Bernardi and Threadgill (2010), Nielson \& Husse, 2010, Kuang and Chen (2011), among others, who found that audit committees comprised of both men and women receive timely audit reports. However, this finding is contrary to the result of Kayleen and Harindahyani (2019) and others, who found no significant relationship between audit committee diversity and audit report time lag.

The control variable results are consistent with earlier research. The findings revealed that audit report time lag is positively correlated with board size, firm age, and firm leverage, whereas audit report time lag is negatively correlated with board independence, firm size, Big4 audit firms and audit committee meetings. These findings are similar with previous research from Bhuiyan and D'Costa (2020), Farooq et al. (2018), Lai et al. (2017), and Abernathy et al (2014), who found a positive association between board size, board independence, big4, company size, and audit report time lag. Firm age, on the other hand, was shown to have no statistically significant impact on audit report time lag in this study, implying that the age of a firm in Ghana has no bearing on audit report time lag.

\subsection{Robustness test}

An alternate measure for audit fees was used to test the robustness and sensitivity of the results obtained from the baseline regression of audit committee characteristics on audit report time lag. We employed the abnormal audit report lag, which have previously been used as proxies for audit report time lag in previous studies (Bhuiyan and D'Costa 2020; Chan et al., 2016; Asthana, 2014). We estimate abnormal audit report lag as the difference between audit report lag day and expected audit report lag day. The robustness test results are provided in table 4 below. The audit committee size, expertise, and gender diversity are all significantly negatively connected to the abnormal audit report lag, according to the robustness test results. By implication, the robustness test results using different proxy for audit report time lag is still consistent with the baseline results provided, proving that audit committee features, in this case audit committee size, expertise, and gender diversity, do indeed lower audit report time lag. Therefore, both the baseline regression result and the robustness test result prove that audit committee characteristics (audit committee size, expertise, and gender diversity) are inversely related to audit report time lag. Hence, the study's findings are resilient even to the estimation of other audit report time lag proxy. 


\begin{tabular}{|c|c|c|}
\hline $\begin{array}{l}\text { AB_ALT } \\
\text { (Abnormal Audit Report Lag) }\end{array}$ & $\begin{array}{c}\text { Model } \\
(1)\end{array}$ & $\begin{array}{c}\text { Model } \\
(2)\end{array}$ \\
\hline ACS & $\begin{array}{l}-0.323 * * * \\
(0.087)\end{array}$ & $\begin{array}{l}-0.241 * * * \\
(0.053)\end{array}$ \\
\hline $\mathrm{ACE}$ & $\begin{array}{l}-0.561 * * * \\
(0.033)\end{array}$ & $\begin{array}{l}-0.404 * * * \\
(0.062)\end{array}$ \\
\hline $\mathrm{ACG}$ & $\begin{array}{l}-0.413 * * \\
(0.183)\end{array}$ & $\begin{array}{l}-0.274 * * \\
(0.096)\end{array}$ \\
\hline $\mathrm{ACM}$ & & $\begin{array}{l}-0.023 \\
(0.046)\end{array}$ \\
\hline BS & & $\begin{array}{l}0.024 * * * \\
(0.006)\end{array}$ \\
\hline $\mathrm{BI}$ & & $\begin{array}{l}-0.036^{* * *} \\
(0.008)\end{array}$ \\
\hline Firm.Age & & $\begin{array}{l}0.023 \\
(0.066)\end{array}$ \\
\hline BIG4 & & $\begin{array}{l}-0.406^{* * *} \\
(0.111)\end{array}$ \\
\hline FirmSize & & $\begin{array}{l}-0.028^{*} \\
(0.015)\end{array}$ \\
\hline Lev & & $\begin{array}{l}0.042 * * * \\
(0.010)\end{array}$ \\
\hline Constant & $\begin{array}{l}0.446 * * * \\
(0.030)\end{array}$ & $\begin{array}{l}0.472 * * * \\
(0.048)\end{array}$ \\
\hline Obs. & 308 & 308 \\
\hline R-squared & 0.501 & 0.698 \\
\hline Year FE & $\mathrm{NO}$ & YES \\
\hline Firm FE & $\mathrm{NO}$ & YES \\
\hline
\end{tabular}

\section{Table 4: Robustness test}

Note: $* * * \mathrm{p}<0.01, * * \mathrm{p}<0.05, * \mathrm{p}<0.1$. AB ATL is Abnormal audit report lag, ACS is audit committee size, ACE is the audit committee financial expertise, $\overline{A C G}$ is the audit committee gender diversity, $\mathrm{BS}$ is the board size, $\mathrm{ACM}$ is audit committee meetings, BI is the board independence (non-executive director), Big4 is audit by the big four audit firm, Firm.Age is firm age, FirmSize is firm size, Lev is firm leverage.

\section{Conclusion and Recommendations}

The study used the case of listed businesses in Ghana to investigate the impact of audit committee features on audit report time lag in the Sub-Saharan region between the period of 2008 and 2019. The study sample consisted of 25 publicly traded companies on the Ghana stock exchange. A typical panel data regression model was used in the investigation. The study found that audit committee features have a significant negative impact on audit report time lag after controlling for both visible and unobservable time invariant factors. The findings of the robustness test further validate the outcome of the baseline model results, suggesting that the result is reliable even when alternative audit report time lag proxy is used.

The study's findings show that audit committee size have a substantial negative relationship with audit report time lag, implying that audit report time lag on average drops as audit committee size increases. This finding supports study hypothesis one and other research that argue that a larger audit committee has the ability to deal with a company's difficulties in a cost-effective and timely manner (Sultana et. al 2015; Mohamad-Nor et al 2010; Farooq et al. 2018). In addition, a negative significant association was discovered between audit committee financial expertise and audit report time lag, indicating that on average audit fees are lower in audit committees with at least one member with accounting or finance knowledge. This conclusion also supports hypothesis two and preceding research, which established that audit committee knowledge is linked to a advanced level of audit assurance through enhanced management oversight and, as a result, a decrease in the scope of work and delay of audit reports (Salleh et al 2017; Sultana et al 2015; Abernathy2014). Moreover, a negative and substantial link between audit committee gender diversity and audit report time lag was discovered, indicating that audit report time lag decrease as the percentage of the audit committee's gender diversity increases. The findings back up hypothesis three and other studies that show that when a woman sits on the audit committee, the firm's internal audit and internal control are more likely to be robust, resulting in timely financial reports. In general, the study's findings provide further insight into the financial reporting system between the audit committee, management, and external auditor.

Consequently, in order to maintain proper oversight and value for money on external audit, the researchers 
urge that firms prioritize gender diversity and financial knowledge in a significant large audit committee size. This is because a big, gender-diverse audit committee with financial knowledge improves the committee's financial reporting monitoring role, which reduces the company's risk level and, as a result, the time spent for quality audit.

We acknowledge that our study has some shortcomings that could lead to future research in related areas. First, the study's scope restricts the findings to Ghana. As a result, future studies will be able to compare Ghana to other developing or African countries. This type of research will be valuable in determining the impact of institutional setting on audit efficiency. Furthermore, these research will aid in explaining how various regulatory requirements affect audit efficiency in various institutional settings. Finally, the study focuses on three aspects of audit committee characteristics: audit committee size, financial skill, and gender diversity, but this description may not be exhaustive. As a result, future research should include other factors such as the race and age of audit committee members.

\section{Disclosure statement}

No potential conflict of interest was reported by the authors

\section{Reference}

Abernathy, J.L., Beyer, B., Masli, A., \& Stefaniak, C.M. (2014). The Association between Characteristics of Audit Committee Accounting Experts, Audit Committee Chairs, and Financial Reporting Timeliness. Advances in Accounting, 30, 283-297.

Abbott, L.J., Parker, S., Peters, G.F. and Raghunandan, K. (2003) The Association between Audit Committee Characteristics and Audit Fees. Auditing: A Journal of Practice \& Theory, 22, 17-32.

Abu, S. O., Yahaya, A. O., \& Abah, C (2018). Audit committee effectiveness and audit quality of Listed Insurance Companies in Nigeria. International Journal of Research in Finance and Management, 1 (2), 35-44.

Afify, H.A.E. 2009. Determinants of audit report lag: Does implementing corporate governance have any impact? Empirical evidence from Egypt. Journal of Applied Accounting Research 10(1): 56-86. doi: $10.1108 / 09675420910963397$

Ahmed, M. I. \& Che-ahmad, A. (2016). Effects of Corporate Governance Characteristics on Audit Report Lags . International Journal of Economics and Financial Issues , 6 (7) , 159-164 . Retrieved from https://dergipark.org.tr/en/pub/ijefi/issue/32000/353050

Agoes, Sukrisno. 2012. Auditing Practical Guidelines for Auditing Accountants by Public Accountants. Jakarta: Four Salemba.

Akle, Y. H. (2011). Financial reporting timeliness in Egypt: a study of the Legal Framework and Accounting Standards. Internal Auditing \& Risk Management.

Asthana, S. (2014). Abnormal audit delays, earnings quality and firm value in the USA. Journal of Financial Reporting and Accounting, 12(1), 21-44. *

Beasley, M. S., J. V. Carcello, D. R. Hermanson, and P. D. Lapides. 2000. Fraudulent financial reporting: Consideration of industry traits and corporate governance mechanisms. Accounting Horizons 14 (December): $14-21$.

Beasley, M. S., \& Salterio, S. E. (2001). The relationship between board characteristics and voluntary improvements in audit committee composition and experience. Contemporary Accounting Research, 18(4), $539-570$

Beasley, M. S. (1996), 'An empirical analysis of the relation between the board of director composition and financial statement fraud', The Accounting Review, Vol. 71, No. 4, pp. 443-65.

Bedard, J., Chtourou, S. M., \& Courteau, L. (2004). The effect of audit committee expertise, independence, and activity on aggressive earnings management. Auditing: A Journal of Practice \& Theory, 23(2), 13-35.

Bédard, J., \& Gendron, Y. (2010). Strengthening the financial reporting system: Can audit committees deliver? International Journal of Auditing, 14(2), 174-210.

Bear S., Rahman N. \& Post C. (2010) The Impact of Board Diversity and Gender Composition on Corporate Social Responsibility and Firm Reputation - Journal of Business Ethics volume 97, pages207-221.

Bernardi, R. A., \& Threadgill, V. H. (2010). Women directors and corporate social responsibility. Electronic Journal of Business Ethics and Organizational Studies, 15 (2), 15-21.

Benedict, A., Gitonga, J. K., Agyeman, A. S., \& Kyei, B. T. (2021). Financial determinants of SMEs performance. Evidence from Kenya leather industry. Small Business International Review, 5(2), e389. https://doi.org/10.26784/sbir.v5i2.389

Behn, B.K., Searcy, D.L. and Woodroof, J.B. (2006), "A within firm analysis of current and expected future audit lag determinants", Journal of Information Systems, Vol. 20 No. 1,pp. 65-86.

Bhuiyan, M.B., \& D'Costa, M. (2020). Audit committee ownership and audit report lag: evidence from Australia. International Journal of Accounting and Information Management, 28, 96-125.

Carmichael, D., Ghosh, A. \& Lee, H. 2011. Causes and consequences of abnormally long audit reporting lags. 
Paper presented at the American Accounting Association Annual Meeting, Colorado. https://aaahq.org/AM2011/abstract.cfm?submissionID=2198

Carcello, J., and T. Neal. 2000. Audit committee composition and auditor reporting. The Accounting Review 75 (October): 453-467.

Carcello, J. V., Hermanson, D. R., Neal, T. L., \& Riley, R. A. (2003). Board characteristics and audit fees. Contemporary Accounting Research, Vol. 19 No. 3, pp. 365-84.

Carcello, J. V., Neal, T. L., Palmrose, Z. \& Scholz, S. (2005), CEO involvement in selecting board members and audit committee effectiveness. Working paper. University of Tennessee, TN.

Chan, K. H., Luo, V. W., \& Mo, P. L. L. (2016). Determinants and implications of long audit reporting lags: Evidence from China. Accounting and Business Research, 46(2), 145-166. *

Choi J. J., Laibson D., and Madrian B., C. (2004) Plan Design and Savings Outcomes - Naional Tax Journal, Volume 57, Number 2.1, https://www.journals.uchicago.edu/toc/ntj/2004/57/2.1

Collier, P., \& Zaman, M. (2005). 'Convergence in European corporate governance: The audit committee concept'. Corporate Governance, Vol. 13, No. 6, pp. 753-68.

Collier, P. and Gregory, A. (1996), "Audit committee effectiveness and the audit fee", European Accounting Review, Vol. 5 No. 2, pp. 177-198.

Dennis, M. R, Kunkel, A. D (2004) - Perceptions of Men, Women, And CEOs: The Effects of Gender Identity: Social Behavior and Personality: an international journal, Volume 32, Number 2, pp. 155-171(17)

DeZoort, F. T. 1997. An investigation of audit committees' oversight responsibilities. Abacus (September): 208227.

Farooq, M.U., Kazim, I., Usman, M. and Latif, I. (2018), “Corporate governance and audit fees: evidence from a developing country", Pakistan Journal of Commerce and Social Sciences, Vol. 12 No. 1, pp. 94-110.

Felix, W. L., Gramling, A. A., \& Maletta, M. J. (2001). The contribution of internal audit as a determinant of external audit fees and factors influencing this contribution. Journal of Accounting Research, 39, 513-534.

Felo, Andrew J., Srinivasan Krishnamurthy, and Steven A. Solieri. 2003. Audit Committee Characteristics and the Perceived Quality of Financial Reporting: An Empirical Analysis. http://dx.doi.org/10.2139/ssrn.401240

Fondas, N., \& Sassalos, S. (2000). A different voice in the boardroom: How the presence of women directors affects board influence over management. Global Focus, 12(2), 13-22.

Galbreath, J. (2018), "Is board gender diversity linked to financial performance? The mediating mechanism of CSR", Business and Society, Vol. 57, pp. 863-889.

Hair, J. F., Black, W. C., Babin, B. J., \& Anderson, R. E. (2009). Multivariate data analysis. Upper Saddle River, NJ: Prentice Hall.

Hillman, A. J., \& Dalziel, T. (2003). Boards of directors and firm performance: Integrating agency and resource dependence perspectives. Academy of Management Review, 28(3), 383-396.

Huse, M., \& Grethe-Solberg, A. (2006). Gender-related boardroom dynamics: How Scandinavian women make and can make contributions on corporate boards. Women in Management Review, 21, 113-130.

H.A.E. Afify, 2009. Determinants of audit report lag: Does implementing corporate governance have any impact? Empirical evidence from Egypt, Journal of Applied Accounting Research, Emerald Group Publishing, vol. 10(1), pages 56-86,

Hashim, U.J., \& Rahman, R.A. (2012). Internal Corporate Governance Mechanisms and Audit Report Lag: A Study of Malaysian Listed Companies. Corporate Board: role, duties and composition, 8, 48-63.

Hendriksen, E.S., van Breda, M.F.. 1992. Accounting Theory. 5th ed. Homewood, IL: Irwin.

Johla, S., Subramaniama, N., \& Zainb, M. M. (2012). Audit Committee and CEO Ethnicity and Audit fees: Some Malaysian evidence. The International Journal of Accounting, p 302-332.

Kalbers, F. L. (1998). Organizational and Economic Explanations of Audit Committee Oversight. Journal of Managerial Issues, Vol. 10, 129-151.

Kuang, X. W., \& Chen, J. (2011). Gender diversity, management control, and auditing demands. Nankai Business Review, 14(6), 48-56.

Kayleen, K., \& Harindahyani, S. (2019). The Impact of Audit Committee's Effectiveness, Gender, and Tenure on Audit Report Lag: Indonesian Evidence. Proceedings of the Proceedings of the 1st

Lai, K. W. \& Cheuk, L. C. (2005), Audit report lag, audit partner rotation and audit firm rotation: Evidence from Australia. Working paper. Hong Kong: City University of Hong Kong

Lee H.Y and Mande V. (2005) The relationship of audit committee characteristics with endogenously determined audit and non-audit fees - Quarterly Journal of Business and Economics Vol. 44, No. 3/4 (Summer - Autumn, 2005), pp. 93-112 (20 pages) Published By: Creighton University.

Li, C. A., \& Wearing, B. (2004). Between glass ceilings: Female non-executive directors in UK quoted companies. International Journal of Disclosure and Governance, 4 (1), 355-372.

Li, J. P., \& Haniffa, R. (2008). Intellectual capital disclosure and corporate governance structure in UK. Accounting and Business Research, 38(2), 136-159. 
Mande, V. and Son, M. (2011), "Do audit delays affect client retention?", Managerial Auditing Journal, Vol. 26 No. 1, pp. 32-50. https://doi.org/10.1108/02686901111090826

Miller, T., \& Del Carmen Triana, M. (2009). Demographic diversity in the boardroom: Mediators of the board diversity-firm performance relationship. Journal of Management Studies, 46, 755-786.

Miglani, S., \& Ahmed, K (2019). Gender diversity on audit committees and its impact on audit fees.: Evidence from India. Accounting Research Journal, 32 (4), 568-586.

McGee R.W. \& T. Tarangelo. (2008). The Timeliness of Financial Reporting and the Russian Banking System: An Empirical Study. In Robert W. McGee (ed.), Accounting Reform in Transition and Developing Economies. New York: Springer

Mohamad-Nor, M. N., Shafie, R., \& Wan-Hussin, W. N. (2010). Corporate Governance and Audit Report Lag in Malaysia. Journal of Accounting and Finance.

Nielsen, S., \& Huse, M. (2010). The contribution of women on boards of directors: Going beyond the surface. Corporate Governance: An International Review, 18, 136-148.

Pincus, K., \& Rusbarsky, M. (1989). Voluntary formation of audit committee among NASDAQ firms. Journal of Accounting andPublic Policy, 239-265.

Person O. S. (2009) Audit committee characteristics and earlier voluntary ethics disclosure among fraud and nofraud firms. International Journal of Disclosure and Governance volume 6, pages284-297 (2009)

Raghunandan, K., W. J. Read, and D. V. Rama. 2001. Audit committee composition, - gray directors, - and interaction with internal auditing. Accounting Horizons (June): 105-118.

Raweh, N. A. M., Kamardin, H., \& Malik, M. (2019). Audit committee characteristics and audit report lag: Evidence from Oman. International Journal of Accounting and Financial Reporting, 9(1), 152-169. https://doi.org/10.5296/ijafr.v9i1.14170

Simon, D. T., and J. R. Francis. 1988. The effects of auditor changes on audit fees: Tests of price cutting and price recovery. The Accounting Review 63 (April): 255-269.

Salleh, Z. (2015). Audit Committee Financial Expertise and Audit Report Lag: Malaysia Further Insights.

Smith Report. (2003). Audit Committees Combined Code Guidance. Report to the Financial Reporting Council. London: Financial Reporting Council.

Soltani, B. (2002), 'Timeliness of corporate and audit reports: Some empirical evidence in the French context', International Journal of Accounting, Vol. 37, No. 2, pp.215-37.

Sultana, N. S., \& Van der Zahn, J. L. (2015). Audit committee characteristics and audit report lag. International Journal of Auditing, 2(19), 72-87.

Thiruvadi, S., \& Huang, H. (2011). Audit committee gender differences and earnings management. Gender in Management: An International Journal, 26(7), 483-498. https://doi.org/10. 1108/17542411111175469

Vafeas, N. and Waegelein, J.F. (2007), "The association between audit committees, compensation incentives, and corporate audit fees", Review of Quantitative Finance and Accounting, Vol. 28 No. 3, pp. 241-255

Xie, B., Davidson, W.N. \& DaDalt, P.J. 2003. Earnings management and corporate governance: The role of the board and the audit committee. Journal of Corporate Finance 9(3): 295-316. doi: http://dx.doi.org/10.1016/S0929-1199(02)00006-8

Yang, J.S. and Krishnan, J. (2005), “Audit committees and quarterly earnings management”, International Journal of Auditing, Vol. 9 No. 3, pp. 201-19.

Yatim, P., Kent, P., \& Clarkson, P. (2006). Governance structures, ethnicity, and audit fees of Malaysian listed firms. Managerial Auditing Journal, pp. 757-782.

Zaitul. (2010). Board of Directors, Audit Committee, Auditor Characteristics and the Timeliness of Financial Reporting in Listed Companies in Indonesia. (Doctoral dissertation, University of Malaysia). Retrieved (26/08/14) from: http://etd.uum.edu . 